medRxiv preprint doi: https://doi.org/10.1101/2020.12.21.20248586; this version posted December 22, 2020. The copyright holder for this

\title{
Routine SARS-CoV-2 wastewater surveillance results in Turkey to follow Covid-19 outbreak
}

Bilge Alpaslan Kocamemi ${ }^{\mathrm{a}}$, Halil Kurt ${ }^{\mathrm{b}}$, Ahmet Sait ${ }^{\mathrm{c}}$, Hamza Kadi ${ }^{\mathrm{d}}$, Fahriye Sarac ${ }^{\mathrm{c}}$, Ismail Aydın $^{\mathrm{d}}$, Ahmet Mete Saatcie, Bekir Pakdemirlif ${ }^{\mathrm{f}}$

\section{Affiliations}

${ }^{a}$ Marmara University, Department of Environmental Engineering, Istanbul, Turkey

${ }^{\mathrm{b}}$ Saglik Bilimleri University, Hamidiye International School of Medicine, Department of Medical Biology, Istanbul, Turkey

${ }^{\mathrm{c}}$ Ministry of Agriculture and Forestry, Republic of Turkey, Veterinary Control Central Research Institute, Pendik, Istanbul, Turkey.

${ }^{\mathrm{d}}$ Ministry of Agriculture and Forestry, Republic of Turkey, Veterinary Control Central Research Institute, Samsun, Turkey.

e Turkish Water Institute, Istanbul, Turkey

${ }^{\mathrm{f}}$ Ministry of Agriculture and Forestry, Republic of Turkey, Ankara, Turkey

\section{Corresponding author}

bilge.alpaslan@marmara.edu.tr

Bilge Alpaslan Kocamemi: Methodology, Data Curation, Formal analysis, Writing - Original Draft, Preparation, Writing - Review \& Editing, Visualization, Supervision, Project administration. Halil Kurt: Validation, Verification, Data Curation, Writing - Review \& Editing. Ahmet Sait, Hamza Kadi: Investigation, Fahriye Sarac, Ismail Aydın: Validation, Ahmet Mete Saatçı : Conceptualization, Writing - Review \& Editing, Supervision, Project administration. Bekir

Pakdemirli: Resources, Funding acquisition

\section{Abstract}

A global pandemic of Coronavirus Disease 2019 (Covid-19) caused by severe acute respiratory syndrome coronavirus 2 (SAR-CoV-2) declared by WHO in March 2019 is still ongoing. As of $13^{\text {th }}$ of December 2020, 70 million people were infected by SARS-CoV-2 and 1.5 million people lost their lives globally (WHO, 2020). Since March 2019, diagnosis of Covid-19 cases has been done through PCR test of samples from nasopharyngeal and throat swabs. However, in March 
medRxiv preprint doi: https://doi.org/10.1101/2020.12.21.20248586; this version posted December 22, 2020. The copyright holder for this

2019, it was reported that the faeces [1] and urine [2] of all infected people contain SARS-CoV-2. Later, numerous researchers [3-7] detected SARS-CoV-2 in faeces of both symptomatic and asymptomatic patients. Moreover, some studies [1,4,8-12] suggested the possibility of extended duration of viral shedding in faeces after the patients' respiratory samples tested negative. In this respect, SARS-CoV-2 wastewater-based epidemiology (WBE), i.e., wastewater surveillance, aiming to estimate the distribution of asymptomatic and symptomatic individuals in a specific region has received worldwide attention. Various research groups worldwide [1, 13-54] have started SARS-CoV-2 detection in wastewater since WBE provides tracking whole population by testing a small number of wastewater samples in a specific region and can predict SARS-CoV-2 RNA in human faeces a few days to a week before onset of symptoms. This makes WBE quite economic tool for continual tracking of decreasing or increasing trend of the Covid-19 in a particular region. However, up to date, almost all of the WBE studies have been performed with samples from a few treatment plants. There was no reported nationwide wastewater surveillance study that has been integrated into a national Covid-19 management strategy by decision makers. Nationwide, SARS-CoV-2 surveillance studies have great potential to reflect the actual distribution of Covid-19 cases in a community by accounting not only symptomatic patients tested but also asymptomatic patients having no or mild symptoms and not been tested. As opposed to clinical surveillance studies, wastewater-based surveillance studies will reflect the number of cases in a community by testing one sample from a treatment plant serving this community instead of performing individual swab tests.

Turkey, which is among the few countries that started wastewater based surveillance studies at the early stages of pandemic is a leading country, performing a nationwide surveillance study. The distribution of Covid-19 cases throughout the country via SARS-CoV-2 measurements in influent, effluent and sludge samples of wastewater treatment plants (WWTPs) located in 81 cities through May 2020- June 2020 was conducted [36, 51, 52]. In June 2020, nationwide routine sampling through 22 regional identified cities has been started. However, from June to September 2020 all samples were detected negative due to problems with RT-pCR primer targeting RdRp gene of SARS-CoV-2 genome. Since September 2020, routine sampling from 22 cities of Turkey with 2 weeks sampling period (weekly for mega city Istanbul) has been continued and regional Covid-19 distributions have been reported as viral loads on color-scale maps. To the best our knowledge, 
medRxiv preprint doi: https://doi.org/10.1101/2020.12.21.20248586; this version posted December 22, 2020. The copyright holder for this

this is the first routine nationwide surveillance study indicating Covid-19 distribution regularly using color-scale presentation on a map.

Keywords: Colored-scale map, Covid-19, nationwide surveillance, SARS-CoV-2, viral load.

\section{Value of the Data}

- A nationwide SARS-CoV-2 surveillance study has been routinely performed first time worldwide

- The measured virus concentrations have been normalized with actual flowrate of WWTP during sampling.

- Covid-19 distribution in a whole country has been demonstrated on a color-scaled map first time worldwide.

\section{Methodology}

\subsection{Sampling}

Routine nationwide wastewater SARS-COV-2 surveillance has been performed in 22 cities of Turkey (Fig. 1). These cities were selected as pilot cities based on population and Covid-19 potentials in regions identified by Turkey Ministry of Health. In these pilot cities, samples were collected at two-week intervals from the influents of the treatment plants serving the maximum population in that city. For mega-city Istanbul, weekly influent samples were collected from two major treatment plants (Fig. 2): Ambarlı WWTP located in the European side of Istanbul and serving about 1.4 million people, Pasakoy WWTP located in the Asian side of Istanbul and serving about 1 million people.

\subsection{SARS-CoV-2 concentration}

Samples were shaken at $4^{\circ} \mathrm{C}$ at $100 \mathrm{rpm}$ for $30 \mathrm{~min}$ in order to transfer attached viruses to the aqueous phase. Microorganisms and large particles were removed from the samples by centrifugation at $7471 \mathrm{G}$ for 30 minutes at 4 degrees celcius. $250 \mathrm{ml}$ of supernatant was filtered through $0.45 \mu \mathrm{m}$ and $0.2 \mu \mathrm{m}$ to remove remaining particles and cell debris. Filtrate was mixed thoroughly with PEG 8000 (10\% w/v) by shaking for 1 minute. The mixture was incubated at $4^{\circ} \mathrm{C}$ at $100 \mathrm{rpm}$ for overnight. Following to the incubation, the mixture was divided in six $50 \mathrm{ml}$ falcon tubes. Viruses were precipitated by centrifugation at $7471 \mathrm{G}$ for 120 minutes at 4 degrees celcius. Supernatant was removed carefully without disturbing the pellets. Pellets of each falcon tubes were re-suspended with $200 \mu \mathrm{RNA}$ free water. $1 \mathrm{ml}$ of virus concentrate was used for total RNA extraction and remaining concentrate stored at $-80^{\circ} \mathrm{C}$. Total viral RNA was extracted either with 
medRxiv preprint doi: https://doi.org/10.1101/2020.12.21.20248586; this version posted December 22, 2020. The copyright holder for this preprint (which was not certified by peer review) is the author/funder, who has granted medRxiv a license to display the preprint in perpetuity.

All rights reserved. No reuse allowed without permission.

Roche MagNA pure LC total nucleic acid isolation kit using Roche MagNA pure LC system in accordance with the manufacturer's protocols (Istanbul Pendik Lab) or manual RNA extraction method (Samsun Lab) . RNA was determined both qualitatively and quantitatively by Thermo NanoDrop 2000c (Penzberg, Germany). Due to high community risk of using SARS-CoV-2 virus, $300 \mu 1$ of $10^{5} \mathrm{copy} / \mathrm{ml}$ surrogate avian coronavirus of Infectious Bronchitis Virus were added our samples in order to evaluate the virus recovery efficiency of PEG 8000 adsorption method. Based on RT-QPCR results, 1-1.5 log virus titer loss were observed after PEG 8000 adsorption and RNA isolation.

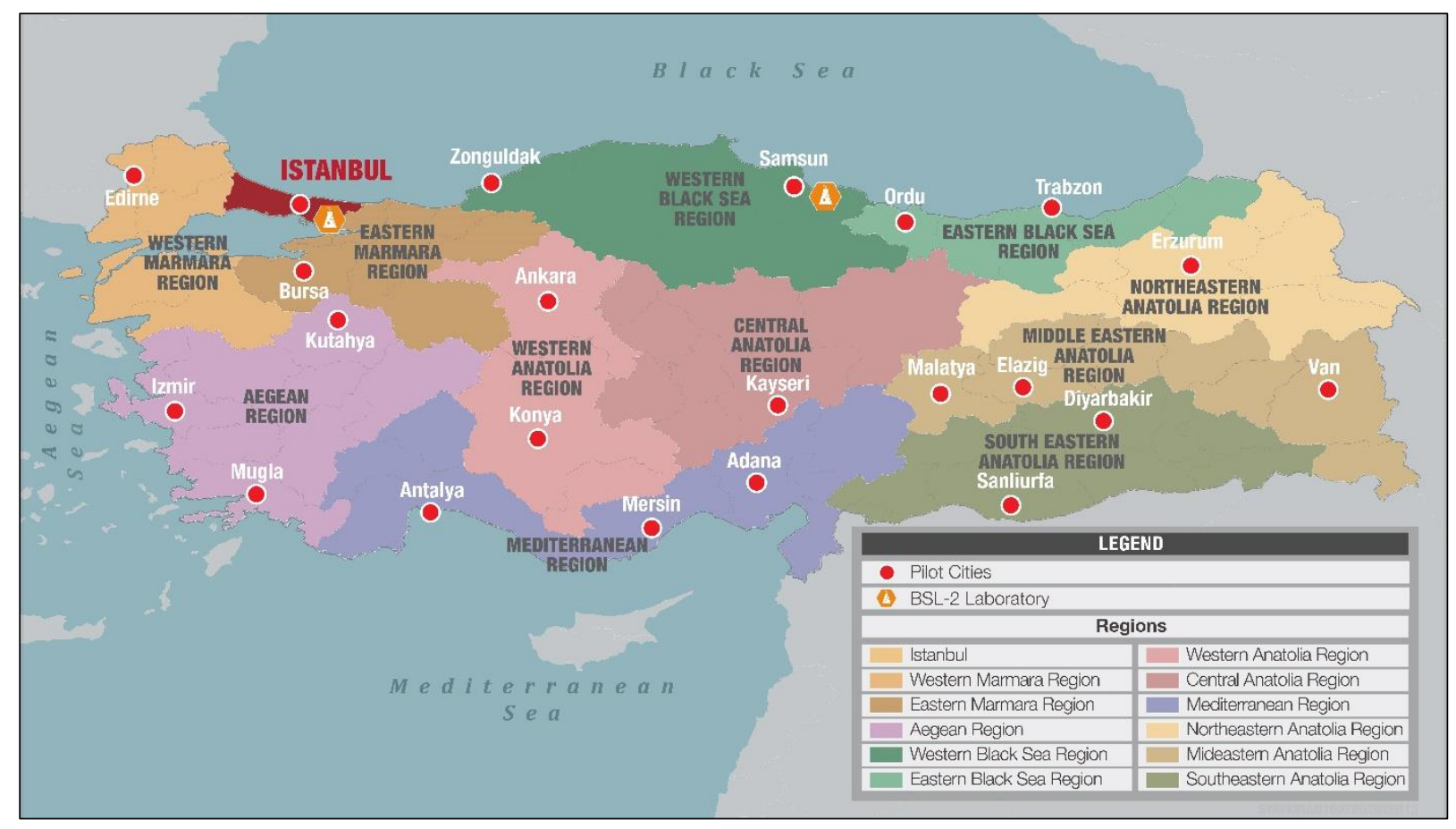

Fig 1. Routine sampling locations in Turkey for nationwide SARS-CoV-2 surveillance study in wastewater 
medRxiv preprint doi: https://doi.org/10.1101/2020.12.21.20248586; this version posted December 22, 2020. The copyright holder for this preprint (which was not certified by peer review) is the author/funder, who has granted medRxiv a license to display the preprint in perpetuity.

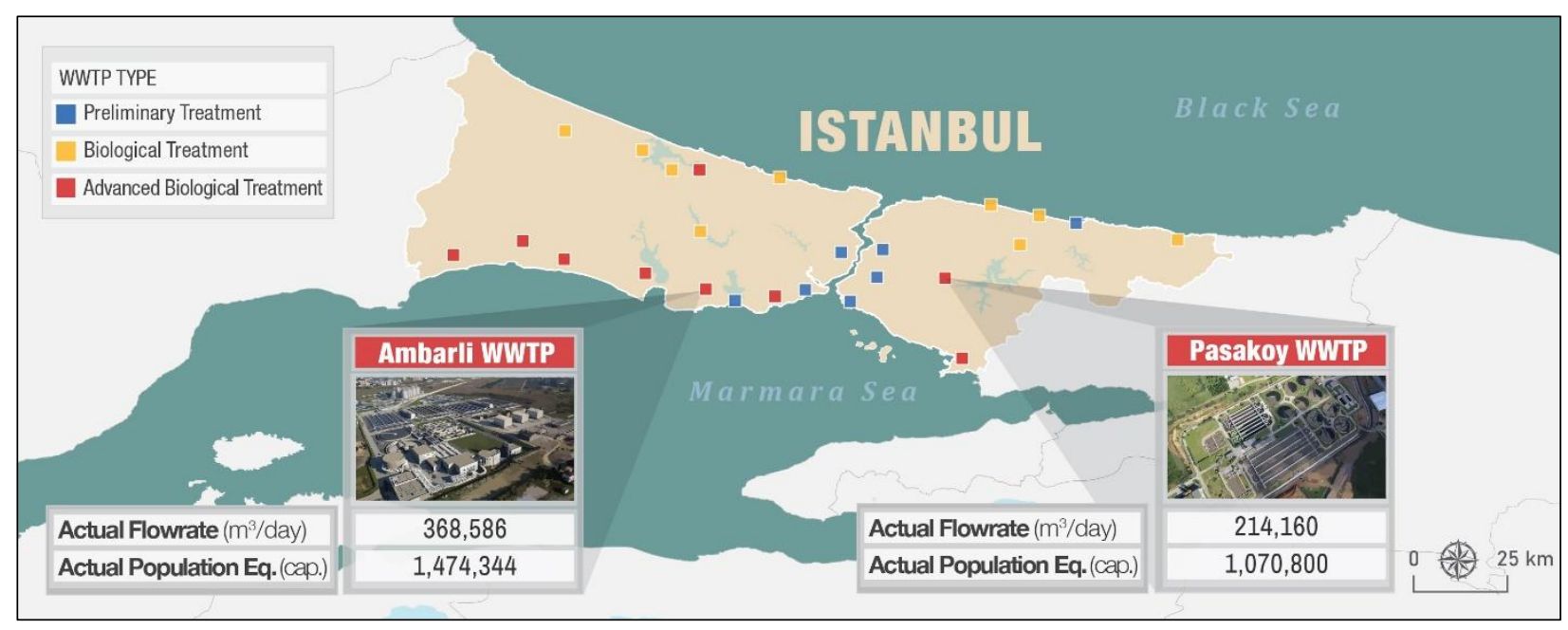

Fig 2. Routine sampling locations in mega city Istanbul for nationwide SARS-CoV-2 surveillance study in Turkey.

\subsection{Quantitative reverse transcription PCR (RT-qPCR)}

Primers and taqman probe sets targeting SARS-CoV-2 N gene [53] were used to detect and quantify SARS-CoV-2 virus. Serial dilutions of synthetic SARS-CoV-2 N gene were used as a standard for absolute quantification. RT-qPCR analysis was performed in Realtime ready RNA virus Master (Roche Diaonostics, Mannhaim, Germany) contained $0.8 \mathrm{nM}$ of forward primer and reverse primer, $0.25 \mathrm{nM}$ probe and $5 \mu \mathrm{L}$ of template RNA. The RT-qPCR assays were performed at $50{ }^{\circ} \mathrm{C}$ for $6 \mathrm{~min}, 53{ }^{\circ} \mathrm{C}$ for $4 \mathrm{~min}, 58^{\circ} \mathrm{C}$ for $4 \mathrm{~min}$ for reverse transcription, followed by $95{ }^{\circ} \mathrm{C}$ for $2 \mathrm{~min}$ and then 45 cycles of $95^{\circ} \mathrm{C}$ for $10 \mathrm{~s}, 55^{\circ} \mathrm{C}$ for $10 \mathrm{~s}$ and $72{ }^{\circ} \mathrm{C}$ for $1 \mathrm{~s}$ for data collection using a Roche LightCycle 2.0 thermal cycler (Roche Diaonostics, Mannhaim, Germany). 
medRxiv preprint doi: https://doi.org/10.1101/2020.12.21.20248586; this version posted December 22, 2020. The copyright holder for this preprint (which was not certified by peer review) is the author/funder, who has granted medRxiv a license to display the preprint in perpetuity. All rights reserved. No reuse allowed without permission.

\section{Data Description}

\subsection{Viral Load Calculation and Color-Scale Presentation on Map}

The SARS-CoV-2 RT-qPCR measurements repeated three times for each sample and results (virus titer/l) were normalized based on the actual flowrates measured at WWTPs in order to present daily viral loads. By considering the minimum and maximum detection limits of RT-qPCR measurements together with minimum and maximum actual flowrates in the pilot cities, the minimum (1E+8 virus titer/day) and the maximum (1E+14 virus titer/day) viral load values, which are possible to observe, were identified. The identified range was then sub-classified under 4 groups on color-scale (Figure 3) as High Case group, Moderate Case group, Low Case group, Very Low Case/ No Case group.

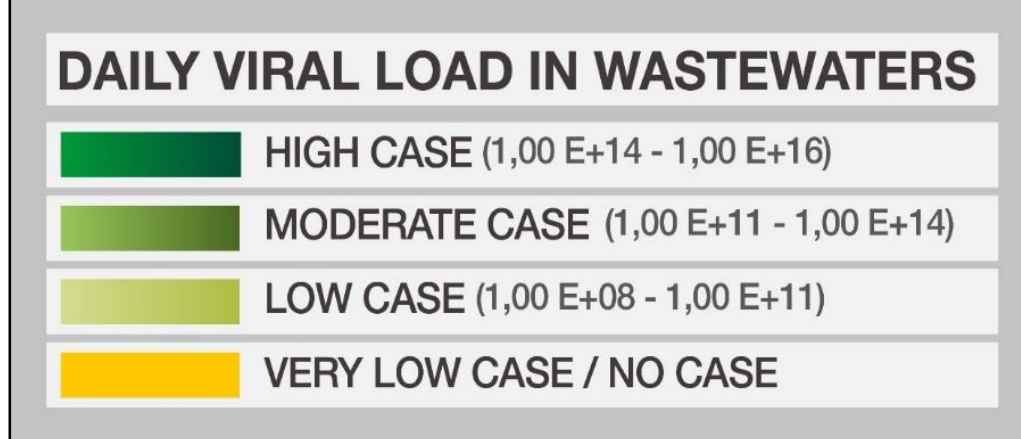

Fig 3. Viral load presentation based on Covid -19 distributions on color-scale

\subsection{Distribution of Covid-19 Cases in Turkey Based on Observed Viral Loads in Wastewater}

The observed viral loads in 21 pilot cities of Turkey are shown color-scale maps in Figure 4. At the beginning of pandemic between May 2020 and June 2020, the Covid-19 cases were mostly in the western part of Turkey, especially in Istanbul, Bursa and Konya in the Middle Anatolian region of Turkey. At that time, Covid-19 cases were low in pilot cities located in the Aegean, Mediterranean and Black Sea regions. Cases were significantly low or absent in the Eastern and Southeastern regions. During routine sampling period, from $15^{\text {th }}$ of October to $15^{\text {th }}$ of November 2020, Covid-19 cases started to spread in low numbers over Middle Anatolian, Mediterranean, Eastern and Southeastern areas. In the period of $15^{\text {th }}$ of November to $15^{\text {th }}$ of December 2020, the Covid-19 cases were distributed over the whole country and reached to moderate levels in the Middle Anatolian, Eastern and Southeastern regions where no or very low cases were observed before November. 
medRxiv preprint doi: https://doi.org/10.1101/2020.12.21.20248586; this version posted December 22, 2020. The copyright holder for this preprint (which was not certified by peer review) is the author/funder, who has granted medRxiv a license to display the preprint in perpetuity. All rights reserved. No reuse allowed without permission.

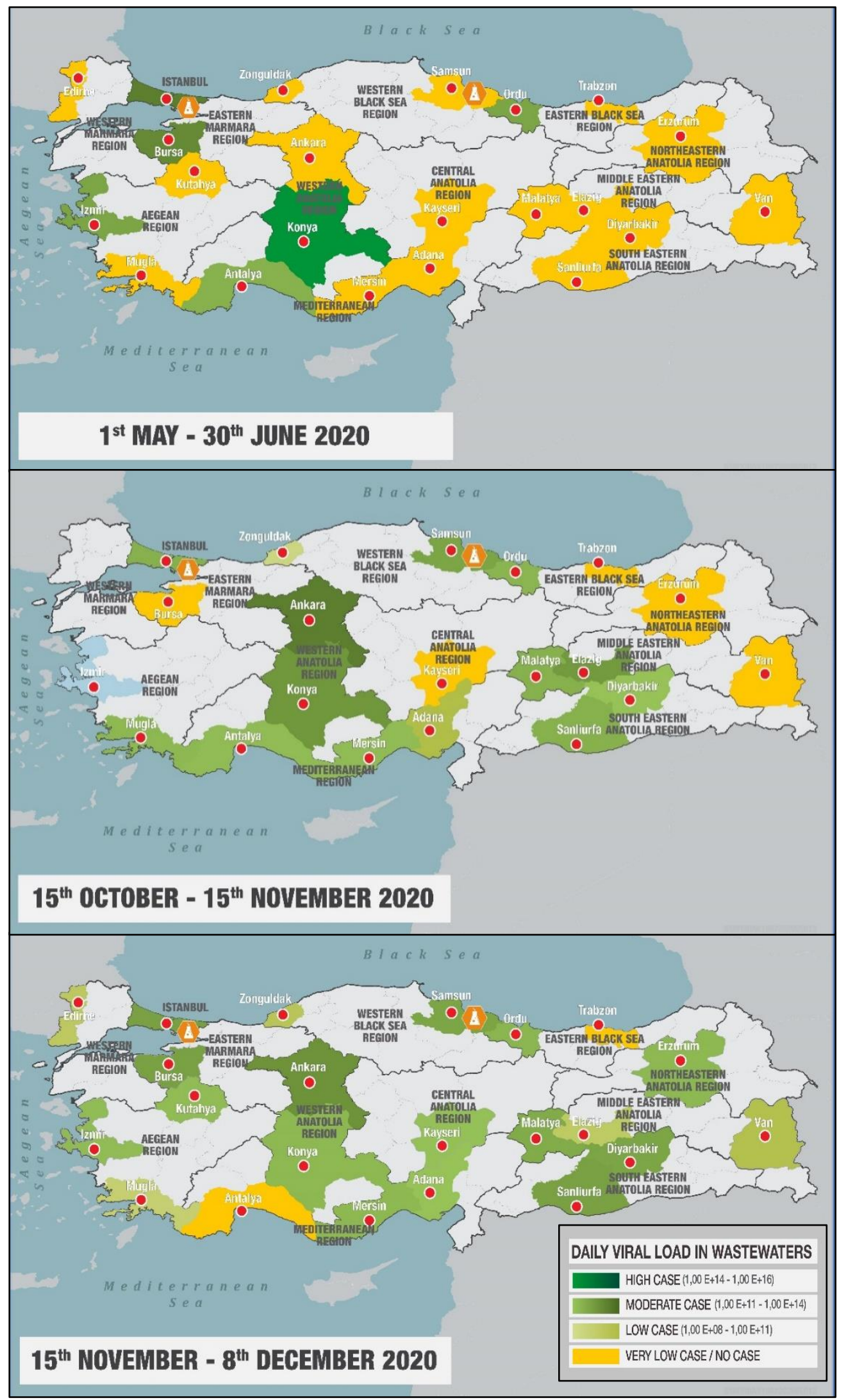

Fig 4. Change of SARS-CoV-2 viral loads throughout Turkey with time. 
medRxiv preprint doi: https://doi.org/10.1101/2020.12.21.20248586; this version posted December 22, 2020. The copyright holder for this preprint (which was not certified by peer review) is the author/funder, who has granted medRxiv a license to display the preprint in perpetuity.

All rights reserved. No reuse allowed without permission.

\subsection{Distribution of Covid-19 Cases in mega-city Istanbul Based on Observed Viral Loads in}

\section{Wastewater}

Since the start of pandemic in Turkey (April 2020), Covid-19 cases have been mostly prevailing in the mega-city of Istanbul with 15 million inhabitants. Figure 5 presents the observed viral loads in Istanbul wastewater since the start of the pandemic. Based on viral loads, Covid-19 cases were very high in April and in May 2020. From June to August 2020, SARS-CoV-2 could not be detected in wastewater due to RTqPCR primer problem explained under Section 1. Starting from August 2020, viral load changes revealed that Covid-19 cases started to increase in October 2020 and reached to a peak in November 2020 resulting in government lock-downs after 9:00 PM and weekends. The positive effect of lockdowns was apparent on viral load map of $1^{\text {st }}$ week of December 2020 which shows the successful applicability of wastewater-based Covid-19 surveillance.

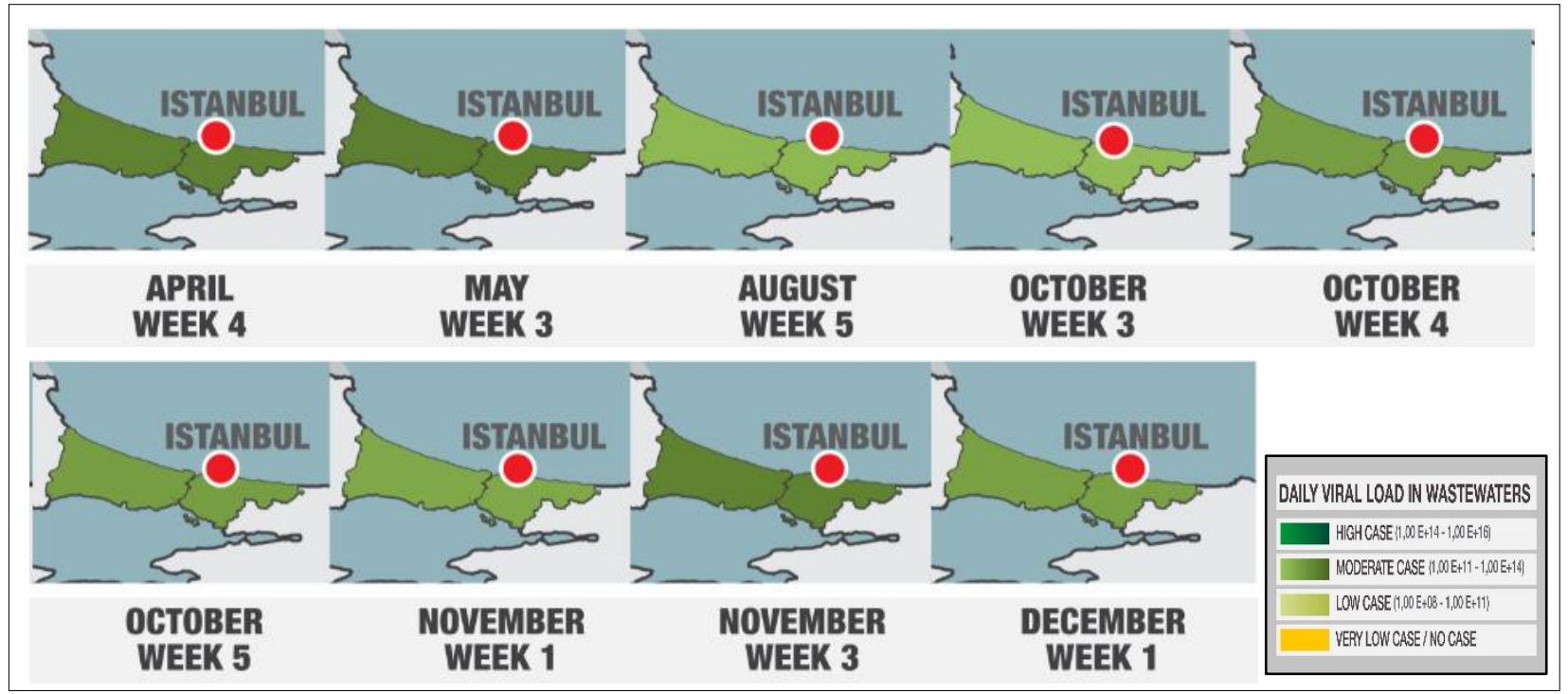

Fig 5. Change of SARS-CoV-2 viral load distributions in Istanbul mega city

\subsection{Correlation of Observed Viral Loads in Wastewater with Case Numbers}

The routine nationwide wastewater surveillance study results of Turkey were further evaluated based on the reported case numbers (Fig. 6). Since the number of cases have been reported regionally, the case numbers shown in Fig. 6 belong to the region of the city that is located. However, while the case number trends vary with viral load changes, it is apparent that viral load trends do not correspond with the change in case numbers. Although, measured viral loads were high in October and did not change significantly in November, the number of reported cases demonstrated an increase from October to November. This observation may indicate the presence of significant numbers of asymptomatic patients in October and may also show the presence of SARS-CoV-2 RNA in human feaces a few days to a week before onset of symptoms. 
medRxiv preprint doi: https://doi.org/10.1101/2020.12.21.20248586; this version posted December 22, 2020. The copyright holder for this preprint (which was not certified by peer review) is the author/funder, who has granted medRxiv a license to display the preprint in perpetuity. All rights reserved. No reuse allowed without permission.

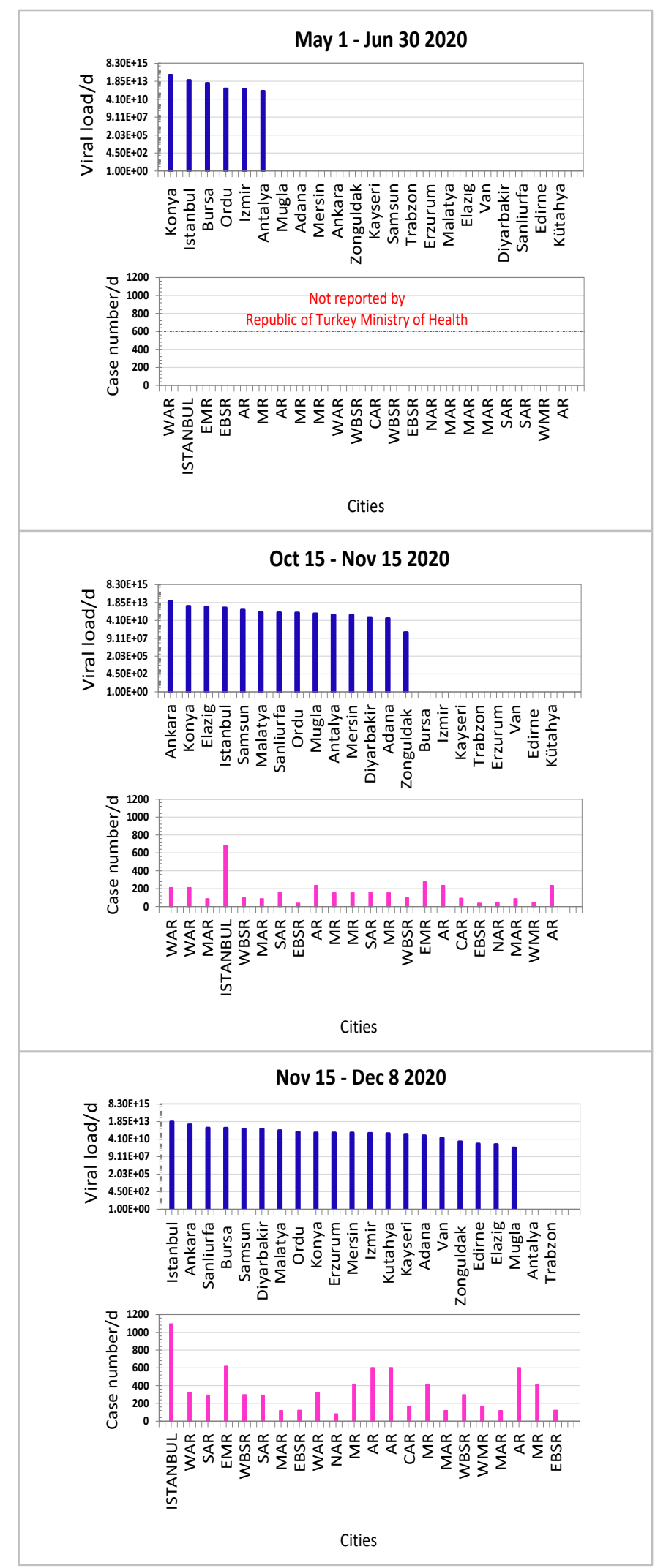

Fig 5. City-based SARS-CoV-2 viral load distributions and regional reported case numbers [54] WMR: Western Marmara Region, EMR: Eastern Marmara Region, WAR: Western Anatolia Region, CAR: Central Anatolia Region; AR: Aegean Region, WBSR: Western Black Sea Region, EBSR: Eastern Black Sea Region, MR: Mediterranean Region, MAR: Mideastern Anatolia Region, NAR: Northeastern Anatolia Region, SAR: Southeastern Anatolia Region 
medRxiv preprint doi: https://doi.org/10.1101/2020.12.21.20248586; this version posted December 22, 2020. The copyright holder for this preprint (which was not certified by peer review) is the author/funder, who has granted medRxiv a license to display the preprint in perpetuity. All rights reserved. No reuse allowed without permission.

\section{Ethics Statement}

The work did not involve any human subject and animal experiments.

\section{Acknowledgments}

This work was financed by Republic of Turkey, Ministry of Agriculture and Forestry.

The authors wish to acknowledge the Turkish Water Institute (SUEN) for the coordination and execution of this study. We wish to express our appreciation to the Ministry`s Istanbul Pendik and Samsun Veterinary Control Central Research Institute for their hard work and rapid analysis of the wastewater samples. We thank to DSI (State Hydraulic Works) for their logistic support for intercity sample transportation. We also thank to all municipalities for their cooperation and efforts to collect and preserve the sewage samples rapidly. Our special thanks to Env. Eng. Salim Yaykıran from SUEN for regional maps and Env.Eng. Sumeyye Celik from Marmara University her contribution to gather and collate up to date information about the worldwide studies on SARS-CoV-2 in wastewater.

\section{Declaration of Competing Interest}

The authors declare that they have no known competing financial interests or personal relationships which have, or could be perceived to have, influenced the work reported in this article.

\section{References}

1. Wu, Y., Guo, C., Tang, L., Hong, Z., Zhou, J., Dong, X., Yin, H., Xiao, Q., Tang, Y., Qu, X., Kuang,L., Fang, X., Mishra, N., Lu, J., Shan, H., Jiang, G. and Huang, X., 2020. Prolonged presence

of SARS-CoV-2 viral RNA in faecal samples. lancet. Gastroenterol. Hepatol. 5,434-435. https://doi.org/10.1016/S2468-1253(20)30083-2.

2. Peng, L., Liu, J., Xu, W., Luo, Q., Deng, K., Lin, B. and Gao, Z. 2020. 2019 Novel Coronavirus can be detected in urine, blood, anal swabs and oropharyngeal swabs samples. medRxiv.

3. Jones, D.L., Baluja, M.Q., Graham, D.W., Corbishley, A., McDonald, J.E., Malham, S.K., Hillary, L.S., Connor, T.R., Gaze, W.H., Moura, I.B., Wilcox, M.H. and Farkas, K. 2020. Shedding of SARS-CoV-2 in feces and urine and its potential role in person-to-person transmission and the environment-based spread of COVID-19, Science of The Total Environment, Volume 749.

https://doi.org/10.1016/j.scitotenv.2020.141364. 
medRxiv preprint doi: https://doi.org/10.1101/2020.12.21.20248586; this version posted December 22, 2020. The copyright holder for this preprint (which was not certified by peer review) is the author/funder, who has granted medRxiv a license to display the preprint in perpetuity. All rights reserved. No reuse allowed without permission.

4. van Doorn, A.S., Meijer, B., Frampton, C.M., Barclay, M.L. and de Boer, N.K. 2020. Systematic review with meta-analysis: SARS-CoV-2 stool testing and the potential for faecal-oral transmission. Alimentary pharmacology \& therapeutics.

5. Jiang, X., Luo, M., Zou, Z., Wang, X., Chen, C. and Qiu, J. 2020. Asymptomatic SARS-CoV2 infected case with viral detection positive in stool but negative in nasopharyngeal samples lasts for 42 days. J Med Virol. 2020 Oct;92(10):1807-1809. doi: 10.1002/jmv.25941.

6.Wölfel, R., Corman, V.M., Guggemos, W., Seilmaier, M., Zange, S., Mueller, M.A., Niemeyer, D., Vollmar, P., Rothe, C., Hoelscher, M., Bleicker, T., Bruenink, S., Schneider, J., Ehmann, R., Zwirglmaier, K., Drosten, C. and Wendtner, C. 2020. Virological assessment of hospitalized cases of coronavirus disease 2019. Nature10.1038/s41586-020-2196-X

7. Tang, A., Tong, Z.D., Wang, H.L., Dai, Y.X., Li, K.F., Liu, J.N., Wu, W.J., Yuan, C., Yu, M.L., Li, P.and Yan. J.B. 2020. Detection of novel coronavirus by RT-PCR in stool specimen from asymptomatic child, China. Emerg. Infect. Dis., 26 (2020), pp. 1-5, 10.3201/eid2606.200301

8. Kitajima, M., Ahmed, W., Bibby, K., Carducci, A. Gerba, C.P., Hamilton, K.A., Haramoto, E. and Joan B. Rose, J.B. 2020. SARS-CoV-2 in wastewater: State of the knowledge and research needs, Science of The Total Environment, Volume 739.

https://doi.org/10.1016/j.scitotenv.2020.139076

9. Wang, W., Xu, Y., Gao, R., Lu, R., Han, K., Wu, G. and Tan, W. 2020. Detection of SARSCoV-2 in Different Types of Clinical Specimens. JAMA, 323(18), 1843-1844. https://doi.org/10.1001/jama.2020.3786.

10. Ling,Y., Xu, S.B., Lin, Y.X., Tian, D., Zhu, Z.Q., Dai, F.H., Wu, F., Song, Gang, Z., Huang, W., Chen, J., Hu, B.J., Wang, S., Mao, E.Q., Zhu, L., Zhang, W.H. and Lu, H.Z., 2020. Persistence and clearance of viral RNA in 2019 novel coronavirus disease rehabilitation patients. Chin. Med. J.133 (9), 1039-1043.

11. Xiao, F., Tang, M., Zheng, X., Liu, Y., Li, X. and Shan, H. 2020. Evidence for Gastrointestinal Infection of SARS-CoV-2. Gastroenterology. 158(6):1831-1833.e3. doi: 10.1053/j.gastro.2020.02.055.

12 Wang, X., Zheng, J., Guo, L., Yao, H., Wang, L., Xia, X. and Zhang, W. 2020. Fecal viral shedding in COVID-19 patients: Clinical significance, viral load dynamics and survival analysis. Virus research, 289, 198147.

https://doi.org/10.1016/j.virusres.2020.198147.

13. Medema, G., Heijnen, L., Elsinga, G., Italiaander, R. and Brouwer,A. 2020. Presence of SARS-Coronavirus-2 RNA in Sewage and Correlation with Reported COVID-19 Prevalence in the Early Stage of the Epidemic in The Netherlands. Environmental Science and Technology Letters 7 (7), 511-516. DOI: 10.1021/acs.estlett.0c00357.

14. Lodder, W. and de Roda Husman, A.M. 2020. SARS-CoV-2 in wastewater: potential health risk, but also data source. Lancet Gastroenterology and Hepatology. doi: 10.1016/S24681253(20)30087-X. 
medRxiv preprint doi: https://doi.org/10.1101/2020.12.21.20248586; this version posted December 22, 2020. The copyright holder for this preprint (which was not certified by peer review) is the author/funder, who has granted medRxiv a license to display the preprint in perpetuity. All rights reserved. No reuse allowed without permission.

15. Medema, G., Heijnen, L., Elsinga, G., Italiaander, R. and Brouwer,A. 2020. Presence of SARS-Coronavirus-2 RNA in Sewage and Correlation with Reported COVID-19 Prevalence in the Early Stage of the Epidemic in The Netherlands. Environmental Science and Technology Letters 7 (7), 511-516. DOI: 10.1021/acs.estlett.0c00357.

16. Nemudryi, A., Nemudraia, A., Surya, K., Wiegand, T., Buyukyoruk, M., Wilkinson, R. and Wiedenheft, B. 2020. Temporal detection and phylogenetic assessment of SARS-CoV-2 in $\begin{array}{lll}\text { municipal } \quad \text { wastewater. } & \text { MedRxiv. }\end{array}$ https://doi.org/10.1101/2020.04.15.20066746.

17. Green, H., Wilder, M., Middleton, F.A., Collins, M., Fenty, A., Gentile, K., Kmush, B., Zeng, T. and Larsen, D.A. 2020. Quantification of SARS-CoV-2 and cross-assembly phage (crAssphage) from wastewater to monitor coronavirus transmission within communities. https://doi.org/10.1101/2020.05.21.20109181.

18. Wu, F., Xiao, A., Zhang, J., Moniz, K., Endo, N., Armas, F., Bonneau, R., Brown, M.A., Bushman, M., Chai, P.R., Duvallet, C., Erickson, T.B., Foppe, K., Ghaeli, N., Gu, X., Hanage, W.P., Huang, K.H., Lee, W.L., Matus, M., McElroy, K.A., Nagler, J., Rhode, S.F., Santillana, M., Tucker, J.A., Wuertz, S., Zhao, S., Thompson, J. and Alm, E.J. 2020. SARS-CoV-2 titers in wastewater foreshadow dynamics and clinical presentation of new COVID-19 cases. https://doi.org/10.1101/2020.06.15.20117747.

19. Curtis, K., Keeling, D., Yetka, K., Larson, A. and Gonzalez, R. 2020. Wastewater SARS-CoV2 Concentration and Loading Variability from Grab and 24-Hour Composite Samples. https://doi.org/10.1101/2020.07.10.20150607.

20. Weidhaas, J., Aanderud, Z., Roper, D., Vanderslice, J., Gaddis, E., Ostermiller, J., Hoffman, K., Jamal, R., Heck, P., Zhang, Y., Torgersen, K., Laan, J.V., Lacross, N., 2020. Correlation of SARS-CoV-2 RNA in wastewater with COVID-19 disease burden in sewersheds. doi:10.21203/rs.3.rs-40452/v1.

21. Sherchan, S. P., Shahin, S., Ward, L.M., Tandukar, S., Aw, T.G., Schmitz, B., Ahmed, W. And Kitajima, M.2020. First detection of SARS-CoV-2 RNA in wastewater in North America: A study in Louisiana, USA, Science of The Total Environment,Volume 743,140621.

https://doi.org/10.1016/j.scitotenv.2020.140621.

22.Ahmed, W., Angel, N., Edson, J., Bibby, K., Bivins, A., O’Brien, J.W., Choi, P.M., Kitajima, M., Simpson, S.L., Li, J., Tscharke, B., Verhagen, R., Smith, W.J.M., Zaugg, J., Dierens, L., Hugenholtz, P., Thomas, K.V. and Mueller, J.F. 2020. First confirmed detection of SARS-CoV-2 in untreated wastewater in Australia: A proof of concept for the wastewater surveillance of COVID-19 in the community. Science of the Total Environment. 138764. https://doi.org/10.1016/J.SCITOTENV.2020.138764.

23. Wurtzer, S., V. Marechal, V., Mouchel, J.M. and Moulin, L. 2020. Time course quantitative 
medRxiv preprint doi: https://doi.org/10.1101/2020.12.21.20248586; this version posted December 22, 2020. The copyright holder for this preprint (which was not certified by peer review) is the author/funder, who has granted medRxiv a license to display the preprint in perpetuity. All rights reserved. No reuse allowed without permission.

detection of SARS-CoV-2 in Parisian wastewaters correlates with COVID-19 confirmed cases, MedRxiv. 2020.04.12.20062679. https://doi.org/10.1101/2020.04.12.20062679.

24. Wurtzer, S., $\quad$ Marechal, V., $\quad$ Mouchel, $\quad$ J.M., Maday, Y., $\quad$ Teyssou, R., Richard, E., Almayrac, J.L. and Moulin, L. 2020. Evaluation of lockdown impact on SARS-CoV-2 dynamics through viral genome quantification in Paris wastewaters

https://doi.org/10.1101/2020.04.12.20062679

25. Trottier, J., Darques, R., Mouheb, N.A., Partiot, E., Bakhache, W., Deffieu, M.S. and Gaudin, R. 2020. Post-lockdown detection of SARS-CoV-2 RNA in the wastewater of Montpellier, France. https://doi.org/10.1101/2020.07.08.20148882

26. Wang, J., Feng, H., Zhang, S., Ni, Z., Ni, L., Chen, Y., Zhuo, L., Zhong, Z. and Qu, T. 2020. SARS-CoV-2 RNA detection of hospital isolation wards hygiene monitoring during the Coronavirus Disease 2019 outbreak in a Chinese hospital. International Journal of Infectious Diseases. 94:103-106. doi: 10.1016/j.ijid.2020.04.024.

27. Randazzo, W., Truchado, P., Ferrando, E.C., Simon, P., Allende, A. and Sanchez, G. 2020. SARS-CoV-2 RNA titers in wastewater anticipated COVID-19 occurrence in a low prevalence area, MedRxiv. 2020.04.22.20075200. https://doi.org/10.1101/2020.04.22.20075200.

28. Randazzo, W., Ferrando, E.C., Sanjuan, R., Calap, P.D. and Sanchez, G. 2020. Metropolitan Wastewater Analysis for COVID-19 Epidemiological Surveillance. https://doi.org/10.1101/2020.04.23.20076679.

29. Mera, F., Río, R., Fuente, J., Sancho, M. Hervas, D., Moreno, I., Dominguez, M., Domínguez, L., Gortázar, C. 2020.COVID-19 in a Rural Community: Outbreak Dynamics, Contact Tracing

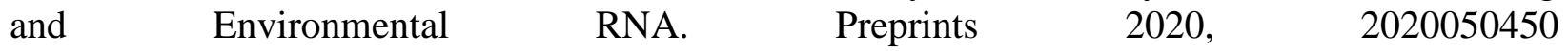
https://www.preprints.org/manuscript/202005.0450/v1.

30. Miró, G. C., Estrada, E. A., Guix, S., Paraira, M., Galofré, B., Sáanchez, G., Pintó, R. and Bosch, A. 2020. Sentinel surveillance of SARS-CoV-2 in wastewater anticipates the occurrence of COVID-19 cases. https://doi.org/10.1101/2020.06.13.20129627.

31. Vallejo, J.A., $\quad$ Feal, S.R., $\quad$ Perez, K.C., $\quad$ Oriona, A.L., $\quad$ Tarrio, J., Reif, R., $\quad$ Ladra, S., Janeiro, B.K.R., Nasser, M., Cid, A., Veiga, M.C., Acevedo, A., Lamora, C., Bou, G., Cao, R. and Poza, M. 2020. Highly predictive regression model of active cases of COVID-19 in a population by screening wastewater viral load. https://doi.org/10.1101/2020.07.02.20144865.

32. La Rosa, G., Iaconelli, M., Mancini, P., Ferraro, G.B., Veneri, C., Bonadonna, L. Lucentini, L and Suffredini E. 2020. First Detection Of Sars-Cov-2 In Untreated Wastewaters In Italy. MedRxiv 2020.04.25.20079830. https://doi.org/10.1101/2020.04.25.20079830. 
medRxiv preprint doi: https://doi.org/10.1101/2020.12.21.20248586; this version posted December 22, 2020. The copyright holder for this preprint (which was not certified by peer review) is the author/funder, who has granted medRxiv a license to display the preprint in perpetuity. All rights reserved. No reuse allowed without permission.

33. Rimoldi, S.G., Stefani, F., Gigantiello, A., Polesello, S., Comandatore, F., Mileto, D., Maresca, M., Longobardi, C., Mancon, A., Romeri, F., Pagani, C., Moja, L., Gismondo, M.R and Salerno, F. 2020. Presence and vitality of SARS-CoV-2 virus in wastewaters and rivers. https://doi.org/10.1101/2020.05.01.20086009.

34. La Rosa, G., Mancini, P., Ferraro, G.B., Veneri, C., Iaconelli, M., Bonadonna, L., Lucentini, L. and Suffredini, E. 2020. SARS-CoV-2 has been circulating in northern Italy since December 2019: evidence from environmental monitoring. https://doi.org/10.1101/2020.06.25.20140061.

35. Or, I.B., Yaniv, K., Shagan, M., Ozer, E., Erster, O., Mendelson, E., Mannasse, B., Shirazi, R., Winter, E.K., Nir, O., Ali, H.A., Ronen, Z., Rinott, E., Lewis, Y. E., Friedler E. F., Paitan, Y., Bitkover, E., Berchenko, Y. and Kushmaro, A. 2020. Regressing SARS-CoV-2 sewage measurements onto COVID-19 burden in the population: a proof-of-concept for quantitative $\begin{array}{llll}\text { environmental } & \text { surveillance. } & \text { 2020.04.26.20073569. }\end{array}$ https://doi.org/10.1101/2020.04.26.20073569.

36. Alpaslan Kocamemi, B., Kurt, H., Hacioglu, S., Yaralı, C., Saatci, A.M. and Pakdemirli, B. 2020. First Data-Set on SARS-CoV-2 Detection for Istanbul Wastewaters in Turkey. MedRxiv. https://doi.org/10.1101/2020.05.03.20089417.

37. Döhla, M., Wilbring, G., Schulte, B., Kümmerer, B.M., Diegmann, C., Sib, E., Richter, E., Haag, A., Engelhart, S., Eis-Hübinger, A.M., Exner, M., Streeck, H. and Schmithausen, R.M. 2020. SARS-CoV-2 in environmental samples of quarantined households. https://doi.org/10.1101/2020.05.28.20114041.

38. Hata, A., Honda, R., Hara-Yamamura, H. and Meuchi, Y. 2020. Detection of SARS-CoV-2 in wastewater in Japan by multiple molecular assays-implication for wastewater-based epidemiology (WBE).

https://doi.org/10.1101/2020.06.09.20126417.

39. Haramoto, F., Malla, B., Thakali, O. and Kitajima, M. 2020. First environmental surveillance for the presence of SARS-CoV-2 RNA in wastewater and river water in Japan. Science of The Total Environment. Volume 737. 40405. https://doi.org/10.1016/j.scitotenv.2020.140405.

40. Kumar, M., Patel, A.K, Shah, A. V., Raval, J., Rajpara, N., Joshi, M. and Joshi, C.G. 2020. First proof of the capability of wastewater surveillance for COVID-19 in India through detection of genetic material of SARS-CoV-2. Science of The Total Environment,Volume 746, 141326. https://doi.org/10.1016/j.scitotenv.2020.141326.

41. Arora, S., Nag, A., Sethi, J., J Rajvanshi, J., Saxena, S., Shrivastava, S. K. and Gupta A.B. 2020. Sewage surveillance for the presence of SARS-CoV-2 genome as a useful wastewater-based epidemiology (WBE) tracking tool in India. https://doi.org/10.1101/2020.06.18.20135277. 
medRxiv preprint doi: https://doi.org/10.1101/2020.12.21.20248586; this version posted December 22, 2020. The copyright holder for this preprint (which was not certified by peer review) is the author/funder, who has granted medRxiv a license to display the preprint in perpetuity. All rights reserved. No reuse allowed without permission.

42. Sharif, S. Ikram, A., Khurshid, A., Salman, M., Mehmood, N., Arshad, Y., Ahmad, J., Angez, M., Alam, M.M., Rehman, L., Mujtaba, G., Hussain, J., Ali, J., Akthar, R., Malik, M.

W., Baig, Z. I., Rana, M. S., Usman, M., Ali, M. Q., Ahad, A., Badar, N., Umair, M., Tamim, S., Ashraf, A., Tahir F. and Ali, N. 2020. Detection of SARS-Coronavirus-2 in wastewater, using the existing environmental surveillance network: An epidemiological gateway to an early warning for COVID-19 in communities.

https://doi.org/10.1101/2020.06.03.20121426.

43. Fongaro, G., Stoco, P.H., Souza, D.S.M., Grisard, E.C., Magri, M.E., Rogovski, P., Schorner, M.A., Barazzetti, F.H., Christoff, A.P., Valter de Oliveira, L.P., Bazzo, M.L., Wagner, G., Hernandez, M. and Lazaro, D.R. 2020. SARS-CoV-2 in human sewage in Santa Catalina, Brazil, November 2019.

https://doi.org/10.1101/2020.06.26.20140731.

44. Prado, T., Fumian, T.M., Mannarino, C.F., Maranhão, A. G., Siqueira, M.M., and Miagostovich, M. P. 2020. Preliminary results of SARS-CoV-2 detection in sewerage system in Niterói municipality. Rio de Janeiro, Brazil. Memórias do Instituto Oswaldo Cruz, 115, e200196. Epub July 27.

45. Ampuero, M., Valenzuela, S., Echeverria, F.V., Rifo, R.S., Barriga, G.P., Chnaiderman, J., Rojas, C., Leiva, S.G., Diez, B. and Gaggero, A. 2020. SARS-CoV-2 Detection in Sewage in Santiago, Chile - Preliminary results. https://doi.org/10.1101/2020.07.02.20145177.

46. Jorgensen, A.U., Gamst, J., Hansen, L.V., Knudsen, I.I.H. and Jensen, S.K.S. 2020. Eurofins Covid-19 Sentinel TM Wastewater Test Provide Early Warning of a potential COVID-19 outbreak.

https://doi.org/10.1101/2020.07.10.20150573.

47. Latorre, L.G., Ballesteros, I., Granda, I.V., Granda,M.G., Paspuel, B.F. and Touma, B.R.2020. SARS-CoV-2 in river water: Implications in low sanitation countries, Science of The Total Environment, Volume 743,140832.

https://doi.org/10.1016/j.scitotenv.2020.140832.

48. Jafferali, M.H., Khatami, K., Atasoy, M., Birgersson, M., Williams, C. and Cetecioglu, Z. 2020. Benchmarking virus concentration methods for quantification of SARS-CoV-2 in raw wastewater.Science of the Total Environment. https://doi.org/10.1016/j.scitotenv.2020.142939

49. Mlejnkova, H., Sovova, K., Vasickova, P., Ocenaskova, V., Jasikova, L., and Juranova, E. 2020. Preliminary Study of Sars-Cov-2 Occurrence in Wastewater in the Czech Republic. International journal of environmental research and public health, 17(15), 5508. https://doi.org/10.3390/ijerph17155508.

50. Ahmed, F., $\quad$ Islam, A., Kumar, M., Hossain, M., $\quad$ Bhattacharya, P., Islam, T., Hossen, F., Hossain, S., Islam, S., Uddin, M., Islam, N., Bahadur, N.M., Alam, D., Reza, H.M 
medRxiv preprint doi: https://doi.org/10.1101/2020.12.21.20248586; this version posted December 22, 2020. The copyright holder for this preprint (which was not certified by peer review) is the author/funder, who has granted medRxiv a license to display the preprint in perpetuity. All rights reserved. No reuse allowed without permission.

and Jakariya, M. 2020. First detection of SARS-CoV-2 genetic material in the vicinity of COVID19 isolation centre through wastewater surveillance in Bangladesh.

https://doi.org/10.1101/2020.09.14.20194696.

51. Alpaslan Kocamemi, B., Kurt, H., Sait, A., Sarac, F., Saatci, A.M. and Pakdemirli, B. 2020. SARS-CoV-2 Detection in Istanbul Wastewater Treatment Plant Sludges. medRxiv, 2020.2005.2012.20099358.

52. Alpaslan Kocamemi, B., Kurt, H., Sait, A., Kadi, H., Sarac, F., Aydin, I., Saatci, A.M. and Pakdemirli, B. 2020. Nationwide SARS-CoV-2 Surveillance Study for Sewage and Sludges of Wastewater Treatment Plants in Turkey.

https://doi.org/10.1101/2020.11.29.20240549.

53. Centers for Disease Control and Prevention. Centers for Disease Control and Prevention; Atlanta: 2020. Research use only 2019-novel Coronavirus (2019-nCoV) real-time RT-PCR primer and probe information [Internet] Available from: https://www.cdc.gov/coronavirus/2019ncov/lab/rt-pcr-panel-primer-probes.html.

54. Republic of Turkey Ministry Covid-19 Information Page. Access date 20.12.2020. Retrieved from https://covid19.saglik.gov.tr/TR-68443/covid-19-durum-raporu.html. 